\title{
A Development of the Blended Learning Model Using Edmodo for Maximizing Students' Oral Proficiency and Motivation
}

\author{
https://doi.org/10.3991/ijet.v12i02.6324 \\ Saovapa Wichadee \\ Bangkok University, Bangkok, Thailand \\ saovapa.w@bu.ac.th
}

\begin{abstract}
The purposes of this study were to develop a blended learning model using Edmodo as a learning tool in language learning and examine the effectiveness of the model implemented in an English course regarding oral proficiency, motivation, and attitude. To achieve these purposes, a quasiexperimental design was employed to collect data using the tests and questionnaires. The samples in this study were the second-year students enrolled in an intermediate English course. The samples were from two classes, each of which contained 42 students. One class was used for the control group; another one for the experimental group. In the control group, students were only taught in a face-to-face learning environment using the PPP model whereas the experimental group studied through the PPP model in class supported by online learning using Edmodo. The findings indicate that blended learning was more effective than traditional learning. That is, students in the experimental group not only outperformed those in the control group in oral proficiency, but they also exhibited higher learning motivation. Although students in both groups did not differ in their attitude toward the PPP model, those in the experimental group expressed a positive attitude toward Edmodo. The findings of this study have implications for English language instructors, encouraging them to see how technology can facilitate learning and help learners produce better academic performance.
\end{abstract}

Keywords—blended learning, Edmodo, oral proficiency, motivation

\section{Introduction}

Oral communication is a vital part of language learning [1]. Oral proficiency refers to the ability to communicate verbally in a functional and accurate way in a target language [2]. A person with a high degree in oral proficiency is able to apply the linguistic knowledge to new situations or contexts. People in Thailand have realized that English oral proficiency is deemed necessary as the country is having more roles 
Paper-A Development of the Blended Learning Model Using Edmodo for Maximizing Students' Oral Proficiency and Motivation

in global community [3]. Especially, when the Asean Community was launched in January 2016, English competency is deemed necessary to compete with others in the labour market. Thai students' poor grasp of communication ability has become a major concern for educators and policy makers. Several obstacles that hinder oral proficiency include inadequate exposure to the English meditated environment [4], the lack of oral practice, the lack of confidence in speaking, and English accent of Thai instructors [5].

One of the models that has been used to develop speaking skill is the "Presentation, Practice and Production (PPP)", starting with introducing the new teaching content, followed by controlled practice and a free practice. This model aims at moving from accuracy to fluency, focusing on form. The first step, "Presentation", is where the instructor examines how much of the target language the students know. The teacher will then present the language structure, usually with a PowerPoint or on a board. The goal of presentation is to "help the learner acquire new linguistic knowledge" [6]. In the second step called "Practice", there is controlled practice of the target language given to the students. This could be in the form of worksheets or oral exercises targeted at individual students. The practice provides learners with repetition of the target structure, followed by generating output including these structures [7]. Practicing really plays a significant role in learning pronunciation and learning lexical chunks. Since accuracy is also regarded as an indicator of the improvement, the main target of practicing is to make learners be able to use the structures to communicate naturally and correctly in real life situations. The instructor can also check whether learners understand the item presented in the first step or not. The third step, "Production", aims at increasing fluency in linguistic use through autonomous and more creative activities [8]. In this step, the students start to produce language more freely. Discussions, role plays and problem-solving activities are sample activities in this step. The levels of fluency are developed as follows:

- Speak slowly with long pauses and/or a lot of incomplete thought

- Speak with frequent pauses, a few incomplete thoughts

- Speak with some stumbling, no incomplete thought

- Speak continuously without pauses or stumbling.

Since the 'Production' step rather takes time and cannot be done much in class, the present study adopted a new kind of technology called "Edmodo" as a supplemental tool that allows more natural learning to increase their fluency. It is believed that students can achieve fluency if they are provided with useful learning resources and activities. The more they learn, the more they make the selected structures comprehensible.

Edmodo is a social media network designed by Jeff O'Hara and Nick Borg in 2008 available at www.edmodo.com [9]. It looks really similar to Facebook, so it is known as "Facebook for school." However, Edmodo is much more private and secure because instructors create accounts and allow students to access and join the group using a code to register in the group [10]. In this regard, instructors can set up a virtual class for students to work together on group assignments [11]. They can share content, discuss topics, receive their instructor feedback and have access to grades very easily. 
Students who are absent will be no longer left behind since they can do a self-study from slides, videos, or worksheets. Due to additional features such as media sharing or socializing, Edmodo can be a replacement of course management system (CMS). Therefore, instructors can apply Edmodo as an enhanced tool in blending learning for course management systems. Edmodo strongly fosters innovation, creativity, active participation and collaboration [12]. Owing to its similar appearance to Facebook that students are familiar with, it is very easy to apply to classrooms of all subjects. As for the attitude toward the use of Edmodo and motivation in learning, a large number of studies showed positive results $[13,14,15,16,17]$.

\section{Overview}

\subsection{Blended learning}

Blended learning has become a key concept in language learning for quite some time. Actually, the term "blended" is extensively and differently used within the context of teaching and learning. It can be defined as combining pedagogical approaches to produce optimum learning outcomes [18] or as a combination of face-to-face learning and teaching mediated by technology [19] which is a focus in this study. It is strongly believed that, in a blended course, conventional learning is supplemented with the use of proper learning technologies. The use of technologies with new teaching methodologies can create innovative learning environments that enable instructors to organize their teaching in a more efficient way. For instance, classroom time can be spent to teach the content suitable for face-to-face meetings. Practices and supplementary resources for the subject matter are offered through the technological tools selected to suit the course contents. Blended learning can remove deficiencies found in the learning process such as time limit of face-to-face classroom. Previous studies reveal positive results of blended learning on learners' performance $[20,21]$.

\subsection{Motivation in learning}

For learners to achieve their goals in online learning, one essential element is motivation which serves as a driving force that propels us to become active [22]. According to Olasina, the way learners interacted and communicated socially with other fellow learners online was closely and affirmatively related with learners' motivation. Learners had been increasingly stimulated to learn due to the introduction and deployment of innovations which proved successful [23]. Learners developed a more favorable attitude toward learning when they experienced blended (or hybrid, or mixed-mode) learning, a combination of actual class time and online learning, where they were allowed a certain amount of control over when, where, and how they learned [24]. Bhatti, Tubaisahat, and El-Quawasmeh [25] found that the less learners depended on the teachers' help, the more satisfied they felt with blended learning. Previous studies were conducted to compare the learning motivation in two teaching 
approaches, and the findings revealed that the blended approach produced more active learning and motivation comparing to the traditional approach [26, 27, 28]

Aforesaid benefits of the blended learning concept strengthened my beliefs and confidence in creating a blended learning model for oral skill development to be used in an English course. Individual learning and in-class assignments may not be enough for non-native students, especially for those with low proficiency of English. Therefore, the focus of this study was to supplement collective knowledge and web-based applications to the course as assignments outside class. The blended learning model was designed based on the course objectives with an aim to help students learn more effectively. It was also designed to solve the problem of limited learning in a traditional setting with an expectation that this model could enhance students' oral proficiency and motivation up to their potential maximum. The results of this study will demonstrate how students' mutual learning can occur with the support of technology and how much group effort on activities in an online learning environment had on their learning outcomes. If the model leads to better language learning and higher motivation, it will be a new choice for redesigning the syllabus of future courses.

Based on the literature review, this study focused on the three variables comprising oral proficiency, learning motivation, and attitude. Therefore, the blended learning model supported by Edmodo was developed in response to the requirement of the EN 013 course which mainly aimed to improve students' oral proficiency. The model was also designed to increase their motivation to learn English and promote positive attitude toward learning.

\subsection{Research objectives}

1. To develop the blended learning model to be implemented in an English course

2. To evaluate the effectiveness of the model

(a) To compare the students' oral proficiency between those in the control group and those in the experimental group after the intervention

(b) To compare the students' learning motivation between the two groups

(c) To compare the students' attitude toward the PPP method between the two groups

(d) To measure the attitude toward the use of Edmodo in blended learning of students in the experimental group

\subsection{Hypotheses}

H1: Students in the experimental group had better oral proficiency than those in the control group.

$\mathrm{H} 2$ : Students in the experimental group had higher motivation than those in the control group.

H3: Students in the experimental group had more positive attitude toward the PPP model than those in the control group. 
Paper-A Development of the Blended Learning Model Using Edmodo for Maximizing Students' Oral Proficiency and Motivation

\section{$3 \quad$ Methodology}

\subsection{Participants}

2,625 students from a private university in Thailand participated in this research. They enrolled in EN013 (3 credits) in semester 1 of academic year 2015. The fact that this research was done at a university made it difficult to randomize each course and allocate it to control and experimental groups. A more viable option was to apply the quasi-experimental design, which allows for control over certain factors that may result in defective experiments [29]. This study employed $\mathrm{G}^{*}$ power to estimate the sample size. Based on an independent t-test with an effect size $d$ of 0.8 , the sample size of each group should be 42 . So, the samples comprised two sections with 42 students in each section. One section was chosen to be the control group while another one was the experimental group. The researcher taught both groups. As the name of the course suggests, EN013 (English for Expressing Ideas) aimed to enhance students' abilities in speaking, conversation, and discussion in a target language. Many activities were included as practical real-life device. The course required students to meet in class once a week for 70 minutes. There were 14 weeks in a semester.

\subsection{Research design}

The quasi-experimental study was designed to compare learning achievement, motivation and attitude between students in a course being taught with blended learning model using Edmodo (the experimental group) and those being taught regularly in class only (control group). Both groups began with a study in a face-to-face setting for five weeks when there was still no treatment applied to them. Most time was spent on the content from the textbook. During weeks 8-12, students in the experimental group were provided with access to online learning called "Edmodo" which was employed to support face-to-face learning, whereas students in the control group were involved with face-to-face learning only.

\subsection{Instruments}

Three instruments including proficiency tests and two sets of questionnaire measuring motivation and attitude were employed in the study. The first instrument was the tests which were used to assess students' abilities in discussing and doing role play in both groups. The first small group discussion test was done in week 6 and the second test in week 13. Also, there were two role plays students had to perform. The first one was done as the mid-term score in week 7 and another one was done in week 14 for final grading. Each test contained 10 points. Therefore, there were 20 points for the pre-test, and 20 points for the post-test.

The second instrument in this study was a motivational questionnaire adapted from Keller's Course Interest Survey [30] to suit the Thai context. It consisted of 10 items 
with five rating scale replies $(1=$ strongly disagree, $2=$ disagree, $3=$ neither agree nor disagree, 4 = agree, and $5=$ strongly agree). The third instrument was a questionnaire surveying attitude comprising two parts: attitude toward the PPP model and attitude toward Edmodo. The first part contained 10 items while the second part had 15 items with five rating scale responses $(1=$ strongly disagree, $2=$ disagree, $3=$ neither agree nor disagree, $4=$ agree, and $5=$ strongly agree). Both parts were given to the experimental group, but the control group received only the first part. As everyone knows, the instructor's selection of software determines the way students interact. Edmodo was selected to use as a learning tool because it can support collaborative learning and working together.

The Likert scale items in the motivational and attitudinal questionnaires were evaluated for the content validity by means of IOC: Index of item objective congruence by three experts. The results showed that all items could be reserved as they possessed proper index (0.66-1.00). In order to determine internal consistency reliability, the questionnaires were piloted with 40 undergraduate students in another class and calculated to find out Cronbach's Alpha coefficients. As for the motivation questionnaire, the alpha coefficient value of 0.924 indicated that the reliability of the questionnaire was high. Attitude toward the PPP model, with the alpha coefficient value of 0.822 and attitude toward Edmodo, with the alpha coefficient value of 0.875 also indicated a level of rather high reliability of the questionnaire.

\subsection{Data analysis}

The data obtained from the tests and the questionnaires were analyzed quantitatively. To ensure that both the control and experimental groups were as equivalent as possible before the study was carried out, an independent samples t-test was used to determine whether the control group and the experimental group were homogeneous in terms of oral proficiency. Paired samples t-tests were used to find out the development of oral proficiency. When a statistically difference of the pre-test scores between both groups was found, ANCOVA was used to find out whether the experimental group gained higher proficiency than the control group. MANOVA was employed to compare motivation and attitude toward the PPP model between the two groups. Moreover, mean and standard deviation were used to demonstrate motivation, attitude toward the PPP model, and attitude toward Edmodo in all items.

\subsection{The blended learning model of the experimental group}

For the experimental group, after students studied through "the PPP model" they had a chance to do some activities in an on-line learning environment. The key concept of the blended model in this study was based on Vygotsky's social development theory [31], Finocchario \& Brumfit's principles of language teaching [32], and blended learning approach [33]. The author employed Edmodo as a tool to create a mutual learning platform for 42 students in an experimental group. All students were given the code that they used when joining the class. 
Paper-A Development of the Blended Learning Model Using Edmodo for Maximizing Students' Oral Proficiency and Motivation

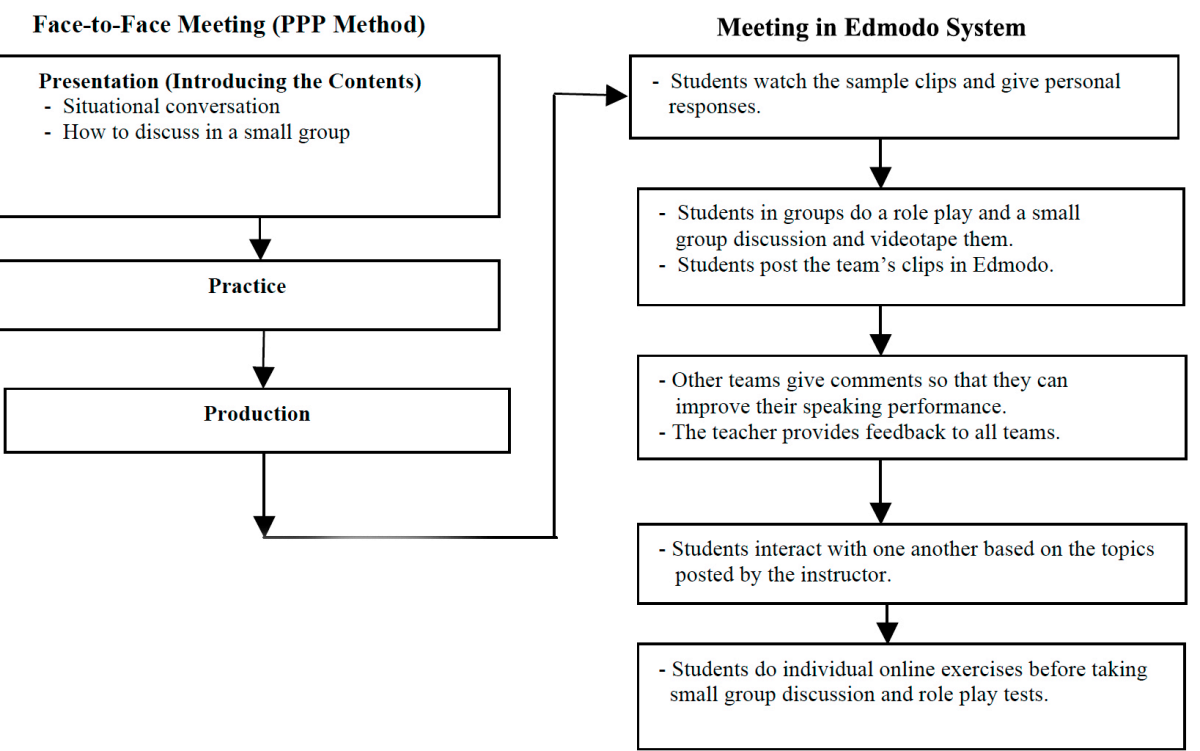

Fig. 1. Blended learning model

They received the traditional PPP teaching plus online learning through Edmodo. Figure 1 demonstrates the treatment given to the experimental group.

In conclusion, certain activities were added in the curricula of the course using Edmodo as follows:

1. Before doing a role play, the instructor uploaded key words followed by several examples of role playing in Edmodo system. Then students in groups created their own script by integrating knowledge into action. When they got stuck on script writing, they could post questions. Often, other students had answered those questions before the instructor did. By so doing, students developed the skills of initiative, communication, and problem solving. This transformed the old way of learning to collaborative and active learning. After each team had posted the clips of role play in Edmodo, they would receive comments from the instructor and peers.

2. The students in groups of four had to prepare a 5-minute talk on the same topic that they had discussed earlier in class, recorded themselves and uploaded the clips in Edmodo system. Those clips could be watched and commented by the instructor and other students. By getting different comments or suggestions in terms of fluency, pronunciation, facial expressions, etc, students could improve their speaking performances, which could hardly be done in traditional large-sized classes.

3. Edmodo enabled the students to realize the topics to be discussed in the next class. So, they could search the content to support their discussion in advance. Traditionally, questions for next class discussion were written on board. This took quite a large amount of time and was often in vain because students did not like to take notes of them or they might forget what they had to prepare. 
4. Before students took the tests of small group discussion and role play in week 1314 , they had a chance to do the online exercises to check how well they could use language in various situations. Questions were kind of multiple choices and matching.

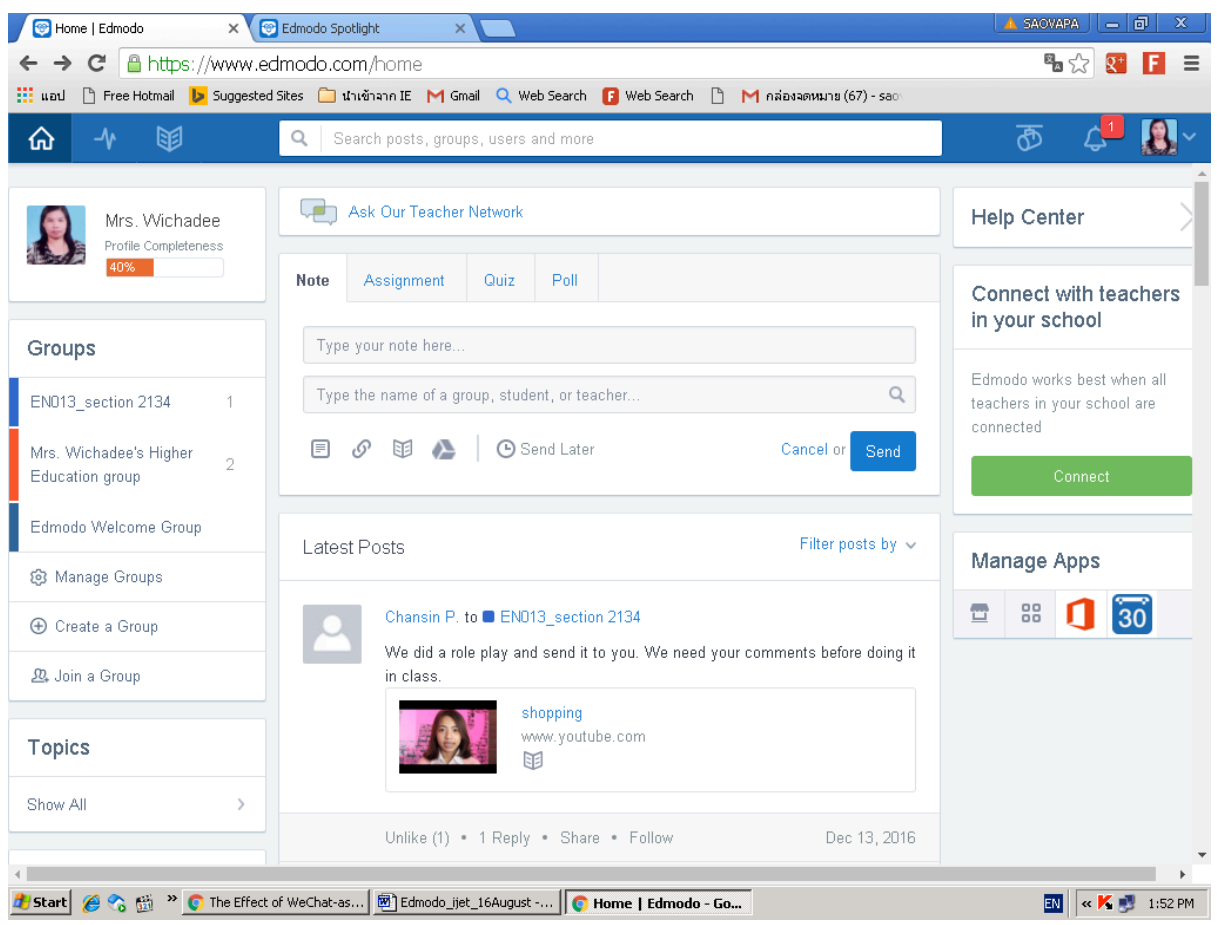

Fig. 2. Screenshot of instructor's Edmodo platform

\section{$4 \quad$ Findings}

Research Question 1: To what extent did the blended learning model improve students' oral proficiency?

Table 1 shows descriptive statistics for the results of the pre- and post-tests for both groups. The pre-test mean scores of students in the control group and experimental group were 10.81 and 9.74 from 20 points, and those scores increased to 13.52 and 14.71 consecutively after the intervention. Then, paired samples $t$-tests were conducted to see whether each group significantly improved their oral proficiency. From $t$-test analysis, the post-test mean scores were significantly higher than the pre-test mean scores in both groups $(\mathrm{P}=.001)$. It is noted that the mean score of the experimental group improved more than that of the control group with mean differences of 4.97 and 2.71 . 
Paper-A Development of the Blended Learning Model Using Edmodo for Maximizing Students' Oral Proficiency and Motivation

Table 1. Pre-Test And Post-Test Scores

\begin{tabular}{cccccc}
\hline Group & & Pre-test $(\mathbf{n}=\mathbf{4 2})$ & Post-test $(\mathbf{n}=\mathbf{4 2})$ & $\mathbf{t}$ & $\mathbf{p}$ \\
\hline \multirow{2}{*}{ Control } & $\mathrm{X}$ & 10.81 & 13.52 & & \\
& $\mathrm{SD}$ & 1.53 & 1.73 & 11.121 & .001 \\
\multirow{2}{*}{ Experimental } & $\mathrm{X}$ & 9.74 & 14.71 & & \\
& $\mathrm{SD}$ & 1.94 & 2.04 & 24.511 & .001 \\
\hline
\end{tabular}

Then the post-test proficiency scores of both groups were to be compared to test the first hypothesis. To assure that the samples assigned to both groups were initially equal since the pre-test mean score of control group was higher than that of the experimental group $(10.81,9.74)$, an independent samples $t$-test was run to compare their pre-test scores. The result showed $\mathrm{t}=2.809, \mathrm{df}=.82$, and $\mathrm{P}=.003$, indicating that the two groups were not equivalent. It can be concluded that both groups were different in their proficiency at the beginning of the experiment. This suggested that a comparison of post-test scores be analyzed using ANCOVA, using the pre-test score as a covariate.

The first research hypothesis aimed to find out whether students in the experimental group developed higher oral proficiency than those in the control group after the intervention. The results show that students in the experimental group had better oral proficiency than those in the control group after the intervention $(\bar{x}=14.71$, 13.52). To test the hypothesis, the post-test mean scores of the two groups were compared by using ANCOVA. The results from an analysis revealed that oral proficiency of the experimental group was significantly higher than that of the control group $(\mathrm{F}=$ $38.961, \mathrm{P}=.001)$. So, Hypothesis I stating that students in the experimental group had better oral proficiency than those in the control group was accepted.

Table 2. Results Of Ancova Test

\begin{tabular}{cccccc}
\hline Source & SS & df & MS & F & p \\
\hline Corrected Model & $166.407 \mathrm{a}$ & 2 & 83.204 & 43.091 & .001 \\
Intercept & 98.530 & 1 & 98.530 & 51.028 & .001 \\
Covariate: pretest & 136.645 & 1 & 136.645 & 70.768 & .001 \\
group & 75.229 & 1 & 75.229 & 38.961 & .001 \\
Error & 156.402 & 81 & 1.931 & & \\
Total & 17068.000 & 84 & & &
\end{tabular}

Research Question 2: How did the motivation of students in the experimental group differ from that of students in the control group?

At the end of the course, the motivational questionnaire was given to both groups in order to assess their motivation. According to Table 2, it is noteworthy that students in the experimental group had more motivation than those in the control group in eight items including number $1,2,3,4,5,6,7$, and 9 . There were only two items (no. 8 , no.10) that students in the control group had more motivation than those in the experimental group. These items are the activities and the amount of work in the course. When considering each item, it is found that the highest mean scores of both 
Paper-A Development of the Blended Learning Model Using Edmodo for Maximizing Students' Oral Proficiency and Motivation

groups were the same item (no. 2, I actively participate in the activities of this course) even though the mean scores were rather much different $(\bar{x}=4.19,4.40)$.

Table 3. Mean Scores Of Motivation

\begin{tabular}{lcccc}
\hline \multicolumn{1}{c}{ Motivation } & \multicolumn{2}{c}{ Control } & \multicolumn{2}{c}{ Experimental } \\
\cline { 2 - 5 } & $\chi$ & S.D. & X & S.D. \\
\hline 1. I enjoy studying English. & 3.79 & .72 & 4.10 & .62 \\
2. I actively participate in the activities of this course. & 4.19 & .74 & 4.40 & .73 \\
3. I think the given tasks are not too difficult. & 3.95 & .66 & 4.05 & .79 \\
4. I am very satisfied with the course. & 3.67 & .65 & 4.10 & .76 \\
5. I feel confident that I will do well in this course. & 3.69 & .68 & 4.12 & .70 \\
6. The content of this course is useful to me. & 3.79 & .78 & 4.17 & .58 \\
7. The content in this course motivates me to learn. & 3.88 & .74 & 4.17 & .66 \\
8. The activities in the course capture my attention. & 4.12 & .74 & 4.10 & .69 \\
9. This course can develop my language proficiency. & 3.52 & .59 & 3.90 & .69 \\
10. The amount of work in the course is suitable. & 3.93 & .71 & 3.90 & .73 \\
\multicolumn{1}{c}{ Total } & 3.85 & .44 & 4.09 & .41 \\
\hline
\end{tabular}

Research Question 3: How did the attitude toward the PPP model of students in the experimental group differ from that of students in the control group?

After taking the course, students were given the survey of attitude toward the PPP model. According to Table 4, the overall attitude mean scores of the two groups were not much different. Both groups had a positive attitude toward the PPP model $(\overline{\mathrm{x}}=$ $4.01,4.05)$. However, when considering each items, students in the experimental group expressed more positive attitude toward the PPP model than those in the control group in six items $(1,2,4,5,6,9)$.

For students in the control group, the third highest mean score fell on item no. 1 (I am encouraged to speak and interact in English, $\overline{\mathrm{x}}=4.33$ ), followed by item no. 8 (The PPP model enables me to study English more systematically, $\bar{x}=4.24$ ), and item no. 3 (The PPP model is not time consuming, $\bar{x}=4.19$ ). The lowest mean score of attitude was item no. 7 (The PPP model helps me improve my ability to speak naturally, $\bar{x}=3.57)$.

For students in the experimental group, the highest mean score fell on no. 1 (I am encouraged to speak and interact in English, $\bar{x}=4.40$ ), which was the same item as the control group. The items with the second highest mean scores were item no. 4 (I feel comfortable when the teacher uses the PPP model, $\bar{x}=4.12$ ) and item no. 6 (I become more active when studying through the PPP model, $\bar{x}=4.12$ ). The lowest mean score was item no. 9 (The PPP model helps me improve my ability to speak naturally, $\overline{\mathrm{x}}=3.86$ ).

The results from MANOVA analysis (Table 5) revealed that there was a difference in motivation between the experimental group and the control group. That is, motivation of students in the experimental group was significantly higher than those in the control group at a significance level of $.05(\mathrm{~F}=6.551, \mathrm{P}=.006)$. Therefore, the hypothesis stating that students who studied through the blended learning model gained higher motivation than those receiving only the face-to-face setting was accepted. 
However, attitude toward the PPP model of the experimental group was not statistically higher than that of the control group $(\mathrm{F}=.092, \mathrm{P}=0.382)$. As a result, the hypothesis stating that the attitude toward the PPP model of the experimental group was more positive than that of the control group was rejected.

Table 4. Mean Scores Of Attitude

\begin{tabular}{|c|c|c|c|c|}
\hline \multirow[t]{2}{*}{ Attitude toward the PPP Model } & \multicolumn{2}{|c|}{ Control } & \multicolumn{2}{|c|}{ Experimental } \\
\hline & $\mathrm{X}$ & S.D. & $\mathrm{X}$ & S.D. \\
\hline $\begin{array}{l}\text { 1. Through the PPP model, I am encouraged to speak and } \\
\text { interact in English. }\end{array}$ & 4.33 & .75 & 4.40 & .70 \\
\hline 2. The PPP model is an effective way to learn English. & 3.98 & .71 & 4.02 & .68 \\
\hline 3. I think the PPP model is not time consuming. & 4.19 & .71 & 4.00 & .82 \\
\hline 4. I feel comfortable when the teacher uses the PPP model. & 3.88 & .74 & 4.12 & .77 \\
\hline 5. The PPP model helps me speak more fluently. & 3.81 & .71 & 4.07 & .74 \\
\hline $\begin{array}{l}\text { 6. I become more active when studying through the PPP } \\
\text { model. }\end{array}$ & 4.05 & .88 & 4.12 & .63 \\
\hline $\begin{array}{l}\text { 7. I have more confidence in communicating in English } \\
\text { through the PPP model. }\end{array}$ & 4.17 & .79 & 4.00 & .73 \\
\hline 8. The PPP model enables me to study English systematically. & 4.24 & .73 & 3.98 & .71 \\
\hline 9. The PPP model helps me speak English naturally. & 3.57 & .67 & 3.86 & .68 \\
\hline 10. The PPP model makes me have more accuracy in speaking. & 3.93 & .71 & 3.90 & .73 \\
\hline Total & 4.01 & .49 & 4.05 & .51 \\
\hline
\end{tabular}

Table 5. Manova Results

\begin{tabular}{llcccc}
\hline \multicolumn{1}{c}{ Source } & \multicolumn{1}{c}{ Dependent } & SS & MS & F & P \\
\hline \multirow{2}{*}{ Corrected Model } & motivation & $1.190 \mathrm{a}$ & 1.190 & 6.551 & .006 \\
& attitude PPP & $.023 \mathrm{~b}$ & .023 & .092 & .382 \\
Intercept & motivation & 1324.869 & 1324.869 & 7290.757 & .001 \\
& attitude PPP & 1364.880 & 1364.880 & 5366.282 & .001 \\
Teaching Method & motivation & 1.190 & 1.190 & 6.551 & .006 \\
& attitude PPP & .023 & .023 & .092 & .382 \\
Error & motivation & 14.901 & .182 & & \\
\multirow{2}{*}{ Total } & attitude PPP & 20.856 & .254 & & \\
\multirow{2}{*}{ Corrected Model } & motivation & 1340.960 & & & \\
& attitude PPP & 1385.760 & & & \\
\hline
\end{tabular}

a. R Squared $=.074$ (Adjusted R Squared $=.063$ )

b. $\mathrm{R}$ Squared $=.001$ (Adjusted R Squared $=-.011$ )

Research Question 4: How did the students in the experimental group respond to the use of Edmodo in blended learning?

According to Table 6, the overall mean score indicated that students had a positive attitude towards the use of Edmodo in blended learning $(\bar{x}=3.84)$. The highest mean scores of attitude fell on item no. 7 (improving listening skill through the audio files uploaded on Edmodo, $\bar{x}=4.05$ ), and item 13 (improving their speaking skill, $\bar{x}=$ 
Paper-A Development of the Blended Learning Model Using Edmodo for Maximizing Students' Oral Proficiency and Motivation

4.05). The lowest mean score of the questionnaire was item no.1 (allowing me to contact teacher and peers outside classroom, $\bar{x}=3.55$ ). It is interesting to see that students expressed a positive attitude toward the use of Edmodo in all items.

Table 6. Mean Scores Of Attitude Toward Edmodo

\begin{tabular}{lcc}
\hline \multicolumn{1}{c}{ Attitude toward Edomo } & $X$ & S.D. \\
\hline 1. Edmodo allows me to contact my teacher and peers outside classroom. & 3.55 & .70 \\
2. Edmodo is convenient to use in learning. & 3.64 & .57 \\
3. I feel comfortable when interacting online via Edmodo. & 3.76 & .66 \\
4. Edmodo saves time by doing and submitting assignments electronically. & 3.81 & .77 \\
5. I can easily access class materials \& assignments through Edmodo. & 3.93 & .71 \\
6. Edmodo gives me a chance to share my tasks with my teacher and peers. & 4.00 & .66 \\
7. I can improve my listening skill through the audio files uploaded on Edmodo. & 4.05 & .62 \\
8. Edmodo facilitates small group discussions. & 3.81 & .59 \\
9. Edmodo increases my motivation to study this course. & 3.64 & .58 \\
10. Edmodo promotes collaborative learning environment. & 3.81 & .77 \\
11. Edmodo enhances autonomous learning skills. & 3.93 & .71 \\
12. Edmodo allows me to get immediate feedback from the teacher. & 4.00 & .66 \\
13. Edmodo helps to improve my speaking skill. & 4.05 & .62 \\
14. Edmodo helps to acquire new vocabulary. & 3.81 & .59 \\
15. Edmodo helps to improve my grammar/spelling. & 3.76 & .66 \\
\hline Thetal & 3.84 & .37 \\
\hline
\end{tabular}
erate, $3.41-4.20=$ positive, $4.21-5.00=$ very positive.

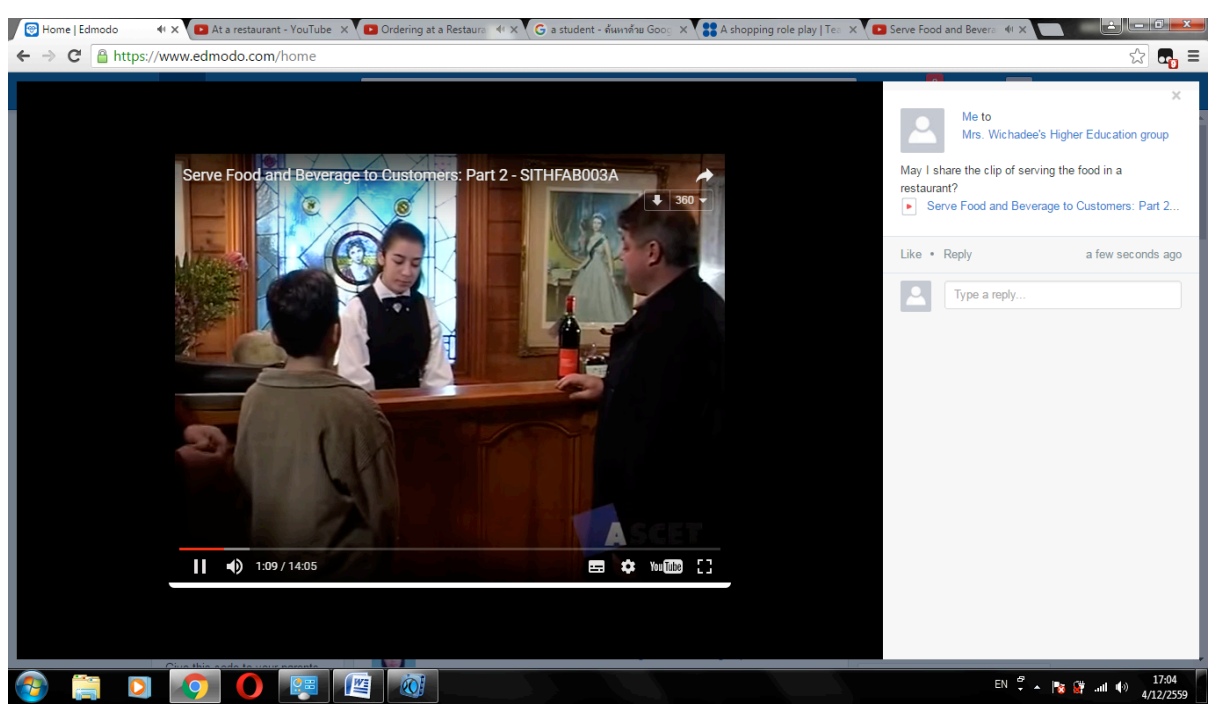

Fig. 3. Sample useful video clip on student's Edmodo page 


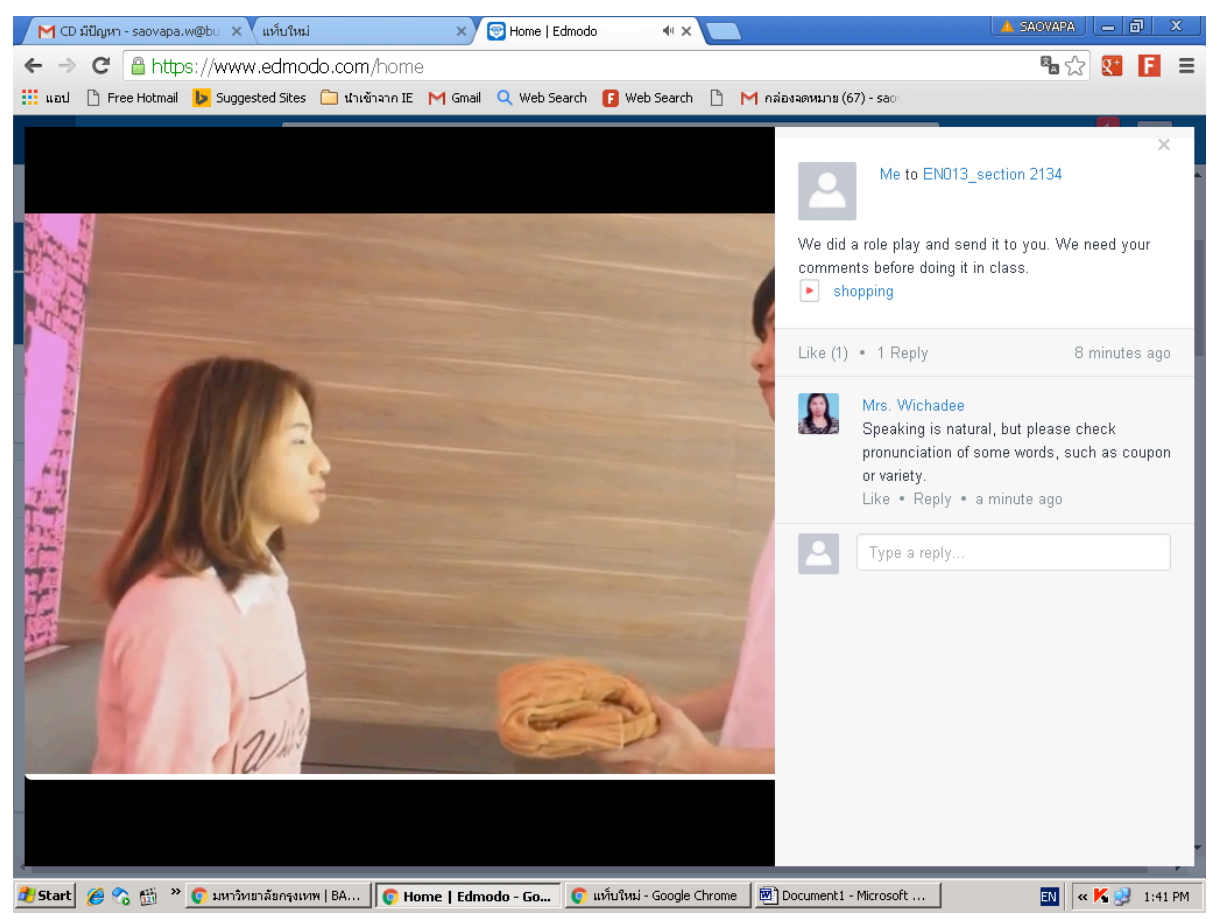

Fig. 4. Screenshot of role play clip posted by students

\section{Discussion}

This study was undertaken to assess, via a pretest-posttest using a quasiexperimental design, the effect of the blended learning model using Edmodo had on students' oral proficiency. The result of the post-test administration indicated that the students in the blended learning group had a better performance than those in the faceto-face group. The results can be explained by two major reasons: collaboration and a blended learning environment which allowed students to learn more actively. Collaborative learning is a contributing factor to active learning. This study has a great benefit of using Edmodo as a supplementary tool in language learning. It is a good collaboration platform for students to learn and to share knowledge [12]. Each team consisted of mix-ability students, offering the opportunities for those with the low oral ability to learn from the suggestion of the more capable members. In addition, students have more chances to watch the sample clips and other clips performed by each team. Not only they learn what other teams performed, they also had to reveal their thoughts. The process of providing personal responses in Edmodo can support social aspect of learning. That is, online communication can be designed to support face-toface oral communication in order to serve the context and anticipated learning objectives [33]. In this study, the traditional teaching supported by technology like Edmodo 
enabled students to learn and practice more. They had personal responses, discussed with others based on the given topics and demonstrated their role plays in Edmodo which is like a stage for them to improve their oral ability. The higher degree of proficiency implied that they could apply the linguistic knowledge to accomplish specific tasks which were new contexts and situations. Students were able to transfer the knowledge gained from the classroom to appropriately use in real-life situations outside of class. The effectiveness of the blended learning model was similar to previous studies which found positive influences on student performance [20, 21].

The survey was carried out to assess learners' perceived motivation with regard to the courses. The findings revealed students in the experimental group had higher motivation than those in the control group. There are several feasible explanations of why the motivation showed a significant difference between the two groups. First of all, the functions of Edmodo are practical; it provides a simple way for instructors and students in a virtual class to connect and collaborate. Students can also share content, submit homework, assignments and quizzes, receive their instructors feedback, notes. They realized that Edmodo really helped to improve their oral proficiency. The blended learning course having a supplementary tool like Edmodo motivated them to learn when compared to the traditional one [12]. Students became more active when they were assigned to do several activities in online learning environments [11]. Secondly, students who had the support of the online supplementary tool in their course were more likely to practice as well as learn from others. In blended learning, there is an integration of web-based resources into instructional practice. It is possible that effective oral communication may come from training and mutual learning in discussions. Pronunciation, facial expressions and language fluency can be developed through comments from peers in blended learning while this could hardly be done in traditional classes. Lastly, students were more aware of the advantages of web-based autonomous English learning through greater communication, where they can determine their own learning speed according to the English level and can get more freedom in the learning process [34]. The finding was found to be similar to the previous study conducted by Chaiprasurt and Esichaikul [28] which revealed that statistically significant differences existed in subjective motivation. The experimental group supported by the online tools achieved a higher level than the control group unsupported by the online tools. Blended courses that utilized the form of asynchronous could enhance students' attitudes toward learning [24].

In this study, the traditional teaching that was employed with both groups was the PPP model. It is interesting to see that both groups had a positive attitude toward this method. The study did not reveal any significant difference between the control and experimental groups in attitude toward the PPP model. This is probably because both groups were rather familiar with the three steps of this model which have been used for quite some time in all English courses. In addition, this may be because the PPP model provides three steps to achieve the learning goal, leading from accuracy to fluency. In the first step, functions that learners need to carry out are introduced systematically such as expressing agreement and disagreement, offering like or dislike. In the practice step, they are able to use language appropriately in specific situations. The last step allows them to integrate the functions of language, information retrieval, 
problem solving, and social interaction [8]. They can deliver the messages more smoothly and fluently. For example, they may be given role play situations to formulate and act out or they may create their own situations in order to have more chances to produce the language they have studied. These useful steps were used to support the result why both groups rated the highest mean score on the same item, indicating that they were strongly encouraged to speak and interact in English.

Regarding the attitude toward the use of Edmodo, students in the experimental group expressed the acceptance of new technology like Edmodo as the finding revealed a positive attitude. This is probably because they believed that Edmodo helped them improve their language proficiency. The finding was similar to many previous studies $[14,15,16,17]$ which found that both instructors and students accepted Edmodo as a great way to get students engaged and organized in learning. It provided various benefits to educational settings. The finding was also in accordance with the highest mean score of the response which stated that Edmodo has a great benefit in improving listening skill through the audio files uploaded. Edmodo is a simple tool for blended learning which suits educational process of $21^{\text {st }}$ century skills allowing for more participation and anytime/anywhere learning. However, it is interesting to see that the lowest mean score was about the use of Edmodo to contact others. The finding indicated that Edmodo was not much used for interacting with the instructor and peers outside classroom. Students may prefer to use other methods to connect the teacher and peers such as LINE or Facebook.

\section{Conclusion}

This study provides support for oral pedagogy based on technological learning tool that allows students to actively engage in understanding, remembering, and eventually being able to apply what they have learned. It also fosters a collaborative learning environment where students are encouraged to communicate and practice conversation with peers. Based on the results, blended learning is an effective way to attain better learning outcomes because students can improve their oral proficiency through active participation in an online classroom community. The blended learning model in this study is, therefore, useful for students since it can promote content connectivity and student interactivity among multiple modes of learning opportunities. With the use of technological support, the course will provide more collective knowledge and web-based applications on outside class assignments that will benefit students. Edmodo appears to be an amazing learning platform which is so user friendly that data show a positive attitude and a high level of acceptance by the participants.

This study, inevitably, has a number of limitations. First of all, even though students work and perform the oral tests in groups, rubric scores are mostly on an individual basis. Knowing this, students do not encourage their peers much before taking the test. Another limitation is about time spent in class. Apart from oral skill practice, students have to study other contents to fulfill the requirement of the course. The last limitation is that the study is conducted in the Thai learning context which is hard to make broad generalizations to others. Despite the limitations, the results of this study 
Paper-A Development of the Blended Learning Model Using Edmodo for Maximizing Students' Oral Proficiency and Motivation

reveal an effectiveness of blended learning supported by technology that promotes mutual learning and collaboration on assignments in an online learning environment. Since the model is helpful in facilitating language learning, it can be a solution for instructors who are facing time limit as well as students who cannot catch up with the lessons in class. However, the issue of digital literacy of learners should be taken into account. Before the lessons start, to ascertain that no student struggles with acquiring the essential skills to work well in an online environment, there should be training in certain skills to facilitate the improvement of their language abilities through the use of technological tools that they have never experienced before such as web 2.0 or some kinds of social media.

\section{$7 \quad$ Acknowledgment}

The researcher would like to thank the Institute of Research Promotion and Innovation Development of Bangkok University for giving financial support.

\section{References}

[1] H. Kayi, "Teaching Speaking: Activities to promote speaking ina second language," The Internet TESL Journal, vol.12, no.11, 2006. Retreived from http://iteslj.org/Techniques/ KayiTeachingSpeaking.html

[2] A. C. Omaggio, Teaching Language in Context: Proficiency-oriented Instruction. Boston: Heinle \& Heinle Publishers, 1986.

[3] W. Van De Bogart, "Developing a Pedagogy for Active Learning (PAL). Academic Journal, vol. 4, pp.146-183, 2009.

[4] A. Wiriyachitra, "A Thai university English Scenario in the Coming Decades," Thai TESOL Newsletter, vol.14, pp.4-7, 2003.

[5] A. Khamkien, "Teaching English Speaking Skills and English Speaking Tests in the Thai Context: A reflection from ThaiPerspective," English Language Teaching, vol.3, pp.184190. 2010

[6] R. Ellis, Second Language Acquisition and Language Pedagogy.Bristol: Longdunn, 1992.

[7] S. Thornbury, How to Teach Grammar. Harlow, Pearson Education, 1999.

[8] R. Criado, A Critical Review of the Presentation-Practice-Production Model (ppp) in Foreign Language Teaching.In R. Monroy (Ed.), Homenaje a Francisco Gutierrez (pp.97115). Murcia: Edit.um., 2013.

[9] C. Kongchan, "How Edmodo and Google Docs Can Change Traditional Classrooms?" Proceedings of the European Conference on Language Learning 2013, Brighton, United Kingdom, paper no.0442, 2013

[10] J. Jarc, "Edmodo-A Free, Web2.0 Classroom Management Too," Retrieved from http://trendingeducation.com/? p=190, 2013.

[11] J. Habley, "AASL Announces 2011 Best Websites for Teaching and Learning," Retrieved fromhttp://americanlibrariesmagazine.or/news.ala/aasl-announces-2011-best-websitesteaching- and- learning, 2011.\#

[12] A. Witherspoon, "Edmodo: A Learning Management System."Retrieved from http://www.poweredwithtechnology.com/, 2011. 
[13] F. Al-Kathiri, "Beyond the Classroom Walls: Edmodo in Saudi Secondary School EFL Instruction, Attitudes andChallenges," English Language Teaching, vol. 8, no.1, pp.189-204, 2015.

[14] G. Arroyo, "On-Line Social Networks: Innovative Ways towards the Boost of Collaborative Language Learning,"ICT for Language Learning (4th ed.). Retrieved from http://conference.pixelonline.net/, 2011.

[15] B. Kandappan, V. Jaykumar and L. Fukey, "A Study on Student Preference towards the Use of Edmodo as a Learning Platform to Create Responsible Learning Environment. Procedia-Social and Behavioral Sciences, vol.144, pp. 416-422, 2014. https://doi.org/10.1016/j.sbspro.2014.07.311

[16] M. Thongmak, "Social Network System in Classroom: Antecedents of Edmodo (C) Adoption," Journal of e-Learningand Higher Education, 2013. https://doi.org/10.5171/2013. 657749

[17] B. Ugur, B. Akkoyunlu and S. Kurbanoglu, "Students' Opinionson blended learning and its implementation in terms of TheirLearning Styles," Education and Information Technologies, vol.16, no.1, pp.5-23, 2011. https://doi.org/10.1007/s10639-009-9109-9

[18] R. Ata, "An Exploration of Higher Education Teaching in SecondLife in the Context of Blended Learning," The Turkish OnlineJournal of Educational Technology, vol.15, no.3, pp. 9-26, 2016.

[19] E. Chew, D. Turner and N. Jones, "In Love and War: Blended Learning Theories for Computer Scientist and Educationalists," In F.L. Wang, J. Fong and R. Kwan, eds. Handbook of Research on Hybrid Learning Models: Advanced Tools, Technologies, and Applications. Hershey, PA: Information Science Reference, 2010. https://doi.org/10.4018/9781-60566-380-7.ch001

[20] M. Jou, Y. Lin and D. Wu, "Effect of a Blended Learning Environment on Student Critical Thinking and KnowledgeTransformation. Interactive Learning Environments, vol.24,no.6, pp.1131-1147, 2016. https://doi.org/10.1080/10494820.2014.961485

[21] G. Motteram, "Blended Education and the Transformation of Teachers: A Long-term Case Study in Postgraduate UKHigher Education," British Journal of Educational Technology, vol.37, no.1, pp.17-30, 2006. https://doi.org/10.1111/j.1467-8535.2005.00511.x

[22] J. Reeve, Understanding Motivation and Emotion (2nd ed.). Orlando: Harcourt College Publishers, 2005.

[23] G. Olasina, "Student's E-learning/M-learning Experiences and Impact on Motivation in Nigeria," Retrieved from http://docs.lib.purdue.edu/iatul/2012/papers/31/, 2012.

[24] D. Wu and R. Hiltz, "Predicting Learning from AsynchronousOnline Discussions," Journal of Asynchronous LearningNetworks, vol.8, no.2, PP.139-152, 2004.

[25] A. Bhatti, A. Tubaisahat and E. El-Qawasmeh, "Using Technology-mediated Learning Environment to OvercomeSocial and Cultural Limitations in Higher Education," Issues in Informing Science and Information Technology, vol.2, pp. 67-76, 2005.

[26] R. Donnelly, "Harmonizing Technology with Interaction in Blended Problem-based Learning," Computers \& Education, vol. 54, no. 2, pp. 350-359, 2010. https://doi.org/10.1016/ j.compedu.2009.08.012

[27] V. Woltering, A. Herrler, K. Spitzer and C. Spreckelsen, "Blended Learning Positively Affects Students' Satisfaction and the Role of the Tutor in the Problem-based Learning Process: Results of a Mixed-Method Evaluation," Advances in Health Science Education, vol. 14, no. 5, pp.725-738, 2009. https://doi.org/10.1007/s10459-009-9154-6

[28] C. Chaiprasurt and V. Esichaikul, "Enhancing Motivation in Online Courses with Mobile Communication Tool Support :A Comparative Study," The International Review of Research in Open and Distance Learning, vol.14, no.3, pp. 377-400, pp. 2014. 
Paper-A Development of the Blended Learning Model Using Edmodo for Maximizing Students' Oral Proficiency and Motivation

[29] J. McMillan and S. Schumacher, Research in Education: A Conceptual Introduction. 4th ed. New York: Longman, 1997.

[30] J. M. Keller, "Development and Use of the ARCS Model of Motivational Design," Journal of Instructional Development,vol.10, no. 3, pp. 2-10, 1987. https://doi.org/10.1007/BF0 2905780

[31] L. S. Vygotsky, Mind in Society. Cambridge, MA: Harvard University Press, 1978.

[32] M. Finoccchiaro and C. Brumfit, The Functional-Notional Approach: From Theory to Practice. $4^{\text {th }}$ ed. Englewood Cliffs,NJ: Prentice Hall, 1983.

[33] C. J. Bonk and C. R. Graham, Handbook of Blended Learning:Global Perspectives, Local Designs. San Francisco, CA: Pfeiffer,2005.

[34] S. Yao, "Research on Web-based Autonomous English Learning of Engineering Students," International Journal of Emerging Technologies in Learning, vol.11, no.6, pp. 4-9, 2016. https://doi.org/10.3991/ijet.v11i06.5802

\section{$9 \quad$ Author}

Saovapa Wichadee is an associate professor at the Language Institute, Bangkok University, Bangkok, Thailand (email: saovapa.w@bu.ac.th).

Article submitted 08 October 2016. Published as resubmitted by the author 21 December 2016. 